\title{
Study of anti-inflammatory activity of omeprazole in complete Freund's adjuvant induced arthritic rats
}

\author{
Nadia Nausheen*, Prabhakar Patil, Yatish Byndoor
}

\begin{abstract}
Department of Pharmacology, Navodaya medical college, Raichur, Karnataka, India

Received: 29 August 2016

Accepted: 28 September 2016

\section{*Correspondence to:}

Dr. Nadia Nausheen

Email: museebrahman@ yahoo.in
\end{abstract}

Copyright: (c) the author(s), publisher and licensee Medip Academy. This is an openaccess article distributed under the terms of the Creative Commons Attribution NonCommercial License, which permits unrestricted noncommercial use, distribution, and reproduction in any medium, provided the original work is properly cited.

\begin{abstract}
Background: Rheumatoid arthritis (RA) is a chronic, progressive, and systemic inflammatory disease, characterized by synovial proliferation and joint erosions. Nonsteroidal anti-inflammatory drugs (NSAIDs) are used as an important part of therapeutic regime to suppress the pain and inflammation associated with RA. The modern drugs both steroidal and nonsteroidal anti-inflammatory drugs (NSAIDS) and disease modifying antirheumatic drugs (DMARDSs) are used for the amelioration of the symptoms of the disease; however, they offer only temporary relief and also produce adverse effects. This study was done to evaluate anti-inflammatory activity of Omeprazole in CFA induced arthritic rats.

Methods: Animals were divided into five groups of six each, group I as control, group II as standard whereas groups III, IV and V as test groups (three doses). Anti-inflammatory effect of group II Diclofenac sodium $(10 \mathrm{mg} / \mathrm{kg}$ orally) and group III, IV and V received Omeprazole $(10 \mathrm{mg} / \mathrm{kg}, 20 \mathrm{mg} / \mathrm{kg}$, and $30 \mathrm{mg} / \mathrm{kg}$ bodyweight orally respectively) was evaluated in adult albino rats by Plethysmometer on 7 th, 14 th and 21 st day post adjuvant injection.

Results: Group 3 produced a significant suppression of paw volume with $P$ value $(<0.05)$ and Group 4 produced a very significant suppression with $\mathrm{P}$ value $(<0.001)$ compared to other groups.
\end{abstract}

Conclusions: Omeprazole, a PPI, has anti-inflammatory activity.

Keywords: CFA, NSAIDS, PPI, RA

\section{INTRODUCTION}

Rheumatoid arthritis (RA) is a chronic, progressive, and systemic inflammatory disease, characterized by synovial proliferation and joint erosions. ${ }^{1}$ Nonsteroidal antiinflammatory drugs (NSAIDs) are used as an important part of therapeutic regime to suppress the pain and inflammation associated with $\mathrm{RA}^{2}{ }^{2}$ The modern drugs both steroidal and nonsteroidal anti-inflammatory drugs (NSAIDS) and disease modifying antirheumatic drugs (DMARDSs) are used for the amelioration of the symptoms of the disease; however, they offer only temporary relief and also produce adverse effects ${ }^{3}$. Proton pump inhibitors (PPIs) are substituted benzimidazoles that block gastric acid secretion by inhibiting $\mathrm{H}+, \mathrm{K}+\mathrm{ATPase}$ the proton pump of the gastric parietal cell. ${ }^{4}$ PPIs are the most effective anti-secretory agents available, and they are among the most commonly used medications in the world. ${ }^{5}$ Recent studies have elucidated a number of mechanisms whereby PPIs can exert anti-inflammatory effects unrelated to the inhibition of gastric acid production. ${ }^{6}$ Those anti-inflammatory properties of the PPIs, which have nothing to do with their effects on parietal cells, may contribute to the beneficial clinical actions of the PPIs, even in acid-peptic disorders. This study was done to evaluate antiinflammatory activity of Omeprazole in CFA induced arthritic rats.

Rheumatoid arthritis (RA) is a long lasting disorder that primarily affects joints. It typically results in warm, swollen, and painful joints. Pain and stiffness often worsen following rest. Most commonly the wrist and hands are involved with typically the same joints involved on both sides of the body. The disease may also affect other parts of the body. Often symptoms come on gradually over weeks to months. ${ }^{7}$

The modern drugs both steroidal and nonsteroidal antiinflammatory drugs (NSAIDS) and disease modifying antirheumatic drugs (DMARDS) are used for the amelioration of the symptoms of the disease; however, 
they offer only temporary relief and also produce adverse effects. $^{3}$

Recent studies have elucidated a number of mechanisms whereby PPIs can exert anti-inflammatory effects unrelated to the inhibition of gastric acid production. ${ }^{6}$

Proton pump inhibitors may exert anti-inflammatory effects by inhibiting the production of pro-inflammatory cytokines that recruit inflammatory cells to diseased tissues. Gastric mucosal production of interleukin-8 (IL8), a potent neutrophil chemo attractant, appears to play an important role in mediating gastric inflammation mediated by infection with H.pylori. ${ }^{8}$ Handa et al. ${ }^{9}$ observed that omeprazole and lansoprazole significantly blocked IL-8 production stimulated by HPE in a human gastric cancer cell line and in human umbilical vein endothelial cells, possibly by interfering with the nuclear factor- $\kappa \mathrm{B}(\mathrm{NF}-\kappa \mathrm{B})$ pathway. In rats treated with indomethacin, Kuroda found that lansoprazole significantly decreased the production of cytokineinduced neutrophil chemoattractant-1 (CINC-1, a rat homologue of IL-8) by the small intestine. ${ }^{10}$ In cultured human tracheal epithelial cells, furthermore, lansoprazole was shown to decrease levels of a number of proinflammatory cytokines including IL-6, IL-8, and tumor necrosis factor-a. ${ }^{11}$

In eosinophilic esophagitis one mechanism that has been proposed for how acid reflux might attract eosinophils to the esophagus involves VCAM-1. ${ }^{12}$ In human esophageal microvascular endothelial cells, acid exposure has been shown to induce the expression of VCAM- $1^{13}$, an adhesion molecule that is recognized by ligands on the eosinophil cell surface. ${ }^{14}$ As discussed above, PPIs have been found to inhibit the expression of VCAM-1 by endothelial cells. ${ }^{15}$

Thus, it is conceivable that PPIs may reduce esophageal eosinophilia, at least in part, by inhibiting VCAM-1 production by esophageal endothelial cells.

In this study we evaluated the anti-inflammatory activity of omeprazole in CFA induced arthritic rats. Adjuvant induced arthritis in rats is a chronic inflammatory disease characterized by infiltration of synovial membrane in association with destruction of joints resembles RA in humans. $^{16}$

\section{METHODS}

A quantitative experimental study in adult albino rats was conducted at Post graduate research laboratory, Department of Pharmacology, Navodaya medical college, Raichur according to ethical norms.

Animals: Wistar albino rats of either sex, weighing 150$200 \mathrm{~g}$ obtained from the National Institute of Nutrition, Hyderabad and maintained at central animal house of Navodaya Medical College under suitable condition of housing, ventilation and nutrition were used for study. Animals were fasted overnight before experiment with free access to water.

Equipments: Syringes, Plethysmometer

\section{Chemicals:}

\section{Complete Freund's agent (CFA)}

CFA, most frequently used arthritic agents as $1 \%$ suspension in normal saline was used to induce arthritis in left hind paw. Not more than $0.1 \mathrm{ml}$ was administered by intra plantar route. CFA was obtained from SIGMA ALDRICH.

\section{Drugs}

Omeprazole and Diclofenac Sodium were obtained from biocid pharmaceutical company.

\section{Induction of arthritis}

Arthritis will be induced in rats by the intra plantar injection of $0.1 \mathrm{ml}$ of CFA in the left hind paw. The adjuvant contained heat killed Mycobacterium tuberculosis in sterile paraffin oil $(10 \mathrm{mg} / \mathrm{ml}) .{ }^{17}$

To induce arthritis 30 rats will be injected with $0.1 \mathrm{ml}$ of complete Freund's adjuvant on their left hind paw. These rats then will be divided into 5 groups. Each group will receive different treatment as follows:

Group 1: Control - Receive $2 \mathrm{ml}$ of distilled water daily

Group 2: Standard - Receive diclofenac sodium 10 $\mathrm{mg} / \mathrm{kg} /$ day orally

Group 3: Omeprazole $10 \mathrm{mg} / \mathrm{kg}$ orally

Group 4: Omeprazole $20 \mathrm{mg} / \mathrm{kg}$ orally

Group 5: Omeprazole $30 \mathrm{mg} / \mathrm{kg}$ orally

Edema formation in the injected hind paw peaked at 3-5 days after injection of the CFA and is measured by calculating percent inhibition of the edema volume of the injected paw.

Percentage inhibition $=\underline{\mathrm{Vc}-\mathrm{Vt}} \times 100$.

Where

$\mathrm{Vc}=$ Volume of paw edema in control animals.

$\mathrm{Vt}=$ Volume of paw edema in treated animals.

Secondary lesions are immunologically mediated changes characterized by inflammation of the non-injected sites. 


\section{Arthritis evaluation}

Primary and secondary lesions

Primary lesion refers to the edema formation in the injected hind paw that peaked 3-5 days after injection of the phlogistic agent and was measured on day 5 by calculating percent inhibition of the edema volume of the injected paw.

Secondary lesions are immunologically mediated changes characterized by inflammation of the non-injected sites (hind leg, forepaws, ears, nose and tail).Changes in Primary (lesions in adjuvant injected paw) and secondary (non-injected paw ) lesions were assessed by using digital Plethysmometer (Marsap) before and on $7^{\text {th }}, 15^{\text {th }}$ and $21^{\text {st }}$ day post adjuvant injection. Body weight was taken every $3^{\text {rd }}$ day after adjuvant injection till $21^{\text {st }}$ day. ${ }^{18}$

\section{Statistical analysis}

Data were subjected to one-way analysis of variance (ANOVA) using SPSS 11.0 software. The results were expressed as "mean increase in paw volume $\pm \mathrm{SD}$ ". Analysis of variance (one way ANOVA) was followed by Dunnett's s t-test for control, standard and test group comparisons were used for statistical evaluation. $\mathrm{P}$ values $<0.05$ were considered as significant.

\section{RESULTS}

Anti-inflammatory activity noted by Plethysmometer after administration of respective drugs.

Table 1: Percentage inhibition of paw volume edema.

\begin{tabular}{|llll|}
\hline Treatment groups & Day 7 & Day 14 & Day 21 \\
\hline $\begin{array}{l}\text { Diclofenac sodium } \\
\text { 10mg/kg }(\mathbf{n}=6)\end{array}$ & 23 & 45 & 60 \\
\hline $\begin{array}{l}\text { Omeprazole } \\
\text { 10mg/kg }(\mathbf{n}=6)\end{array}$ & 10 & 19 & $\mathbf{3 0}$ \\
\hline $\begin{array}{l}\text { Omeprazole } \\
\text { 20mg/kg }(\mathbf{n}=6)\end{array}$ & 15 & 28 & 44 \\
\hline $\begin{array}{l}\text { Omeprazole } \\
\text { 30mg/kg }(\mathbf{n}=6)\end{array}$ & 18 & 41 & 54 \\
\hline
\end{tabular}

The anti-inflammatory effect of omeprazole $20 \mathrm{mg} / \mathrm{kg}$ was significant i.e. $(\mathrm{p}<0.05)$ and Omeprazole $30 \mathrm{mg} / \mathrm{kg}$ was more significant $(\mathrm{P}<0.001)$ at time interval of 21 days.

\section{DISCUSSION}

The present study was carried out to evaluate the antiinflammatory property of omeprazole for this diclofenac sodium was selected as standard drug whereas omeprazole $(10,20,30 \mathrm{mg} / \mathrm{kg} \mathrm{BW})$, where selected as test drugs.

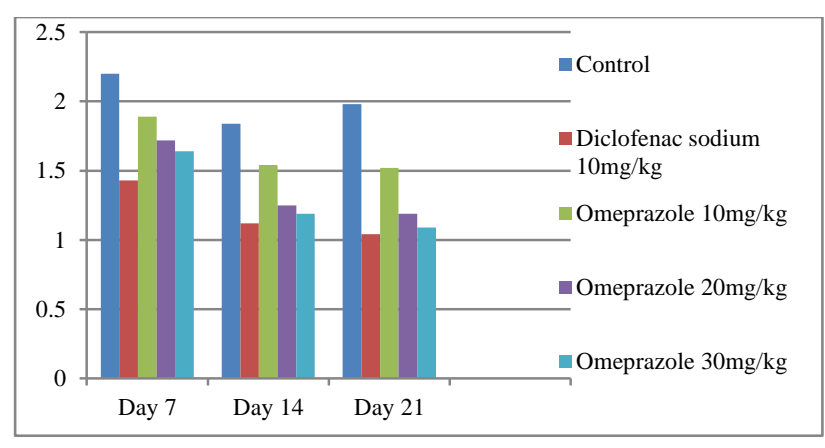

Figure 1: Paw volume edema (Mean \pm SD).

Diclofenac sodium, Non-steroidal anti-inflammatory drug, whereas omeprazole anti-inflammatory drug by suppresses induction of inflammatory mediators like TNF- $\alpha^{19,20}$, IL- $1 \beta^{19}$, IL- $6^{20}$ and induces protective enzyme Heme-oxygenase-1(HO-1 $)^{21}$ and by decreasing proinflammatory cytokines release from the phagocytes.

Total rats were divided into 5 groups, Group 1 rats were considered as controls and treated with normal saline, Group 2 rats as standard and treated with diclofenac sodium $10 \mathrm{mg} / \mathrm{kg}$, Group 3 rats as test-1 and treated with omeprazole $10 \mathrm{mg} / \mathrm{kg}$, Group 4 rats as test- 2 treated with omeprazole $20 \mathrm{mg} / \mathrm{kg}$ and Group 5 rats as test-3 and treated with omeprazole $30 \mathrm{mg} / \mathrm{kg}$ BW.

The readings were recorded using Plethysmometer and results were analysed using Anova test.

\section{CONCLUSION}

From the above study it was concluded that Omeprazole possess significant anti-inflammatory activity. The antiinflammatory activity of Omeprazole was not better than that of the standard drug, Diclofenac sodium, but was almost equal to that of the standard drug, Diclofenac sodium in plethysmometer. The mechanism of antiinflammatory activity is unclear. Other researchers can do further study on its mechanism.

\section{Funding: No funding sources}

Conflict of interest: None declared

Ethical approval: The study was approved by the Institutional Ethics Committee

\section{REFERENCES}

1. Yanni G, Whelan A, Feighery C. Synovial tissue macrophages and joint erosion in rheumatoid arthritis.Annals of the Rheumatic Diseases. 1994;53(1):39-44.

2. Lo V, Meadows SE. When should COX-2 selective NSAIDs be used for osteoarthritis and rheumatoid arthritis? Journal of Family Practice. 2006;55(3):2602.

3. Hazeena Begum V, Sadique J. Long term effect of herbal drug Withania somnifera on adjuvant induced 
arthritis in rats. Indian Journal of Experimental Biology. 1988;26(11):877-82.

4. Shin JM, Sachs G. Pharmacology of proton pump inhibitors. Curr Gastroenterol Rep. 2008;10:528-34.

5. Forgacs I, Loganayagam A. Overprescribing proton pump inhibitors. BMJ. 2008;336:2-3.

6. Namazi MR, Jowkar F. A succinct review of the general and immunological pharmacologic effects of proton pump inhibitors. J Clin Pharm Ther. 2008;33:215-7.

7. Majithia V, Geraci SA. Rheumatoid arthritis: diagnosis and management. Am J Med. 2007;120(11):936-9.

8. Smith WB, Gamble JR, Clark-Lewis I, Vadas MA. Interleukin-8 induces neutrophil transendothelial migration. Immunology 1991;72:65-72.

9. Handa O, Yoshida N, Fujita N. Molecular mechanisms involved in anti-inflammatory effects of proton pump inhibitors. Inflamm Res. 2006;55:47680 .

10. Kuroda M, Yoshida N, Ichikawa H. Lansoprazole, a proton pump inhibitor, reduces then severity of indomethacin-induced rat enteritis. Int $\mathrm{J}$ Mol Med. 2006;17:89-93.

11. Sasaki T, Yamaya M, Yasuda $H$, et al. The proton pump inhibitor lansoprazole inhibits rhinovirus infection in cultured human tracheal epithelial cells. Eur J Pharmacol. 2005;509(2-3):201-10.

12. Spechler SJ, Genta RM, Souza RF. Thoughts on the complex relationship between gastroesophageal reflux disease and eosinophilic esophagitis. Am J Gastroenterol. 2007;102:1301-6.

13. Rafiee $\mathrm{P}$, Theriot ME, Nelson VM. Human esophageal microvascular endothelial cells respond to acidic $\mathrm{pH}$ stress by PI3K/AKT and p38 MAPKregulated induction of $\mathrm{Hsp} 70$ and Hsp27. Am J Physiol Cell Physiol. 2006;291:C931-45.
14. Barthel SR, Annis DS, Mosher DF, Johansson MW. Differential engagement of modules 1 and 4 of vascular cell adhesion molecule-1 (CD106) by integrins alpha4beta1 (CD49d/29) and alphaMbeta2 (CD11b/18) of eosinophils. J Biol Chem. 2006;281:32175-87.

15. Yoshida N, Yoshikawa T, Tanaka Y. A new mechanism for anti-inflammatory actions of proton pump inhibitors inhibitory effects on neutrophilendothelial cell interactions. Aliment Pharmacol Ther. 2000;14(Suppl 1):74-81.

16. Katz L, Piliero SJ, A study of adjuvant induced polyarthritis in the rat with special reference to associated immunological phenomena. Ann New York Acad Sci. 1969;147:515-36.

17. Pashikanti G, Kulundaivelu U. Anti-arthritic activity of ethanolic extract from the leaves of Commiphoracaudata (Linn) in complete freund's adjuvant-induced arthritic rats. Nigerian Journal of Experimental and Clinical Biosciences. 2014;2:1428.

18. Mangesh Bansod S, Virendra Kagathara G, Rohini Pujari R. Therapeutic effect of apoly-herbal preparation on adjuvant induced arthritis in wistar rats. International journal of pharmacy and pharmaceutical sciences. 2011;3:186-92.

19. Hashioka S, Klegeris A, McGeer PL. Proton pump inhibitors exert anti-inflammatory effects and decrease human microglial and monocytic THP-1 cell neurotoxicity. Exp Neurol. 2009;217(1):177-83.

20. Naito Y, Takagi T, Yoshikawa T. Lansoprazole, a proton pump inhibitor to reduce gastrointestinal inflammation via Heme oxygenase-1 induction.Mol Cel Pharmacol. 2010;2(2):53-60.

21. Wandall JH. Effects of omeprazole on neutrophil chemotaxis, superoxide production, degranulation and translocation of cytochrome b-245. Gut. 1992;33:617-21.

Cite this article as: Nausheen N, Patil P, Byndoor Y. Study of anti-inflammatory activity of omeprazole in complete Freund's adjuvant induced arthritic rats. Int J Basic Clin Pharmacol 2016;5:2534-7. 